\title{
Gambaran Pengetahuan Kesehatan Gigi Mulut, Perilaku Kesehatan Gigi Mulut, dan Status Gigi Lansia di Panti Wreda Surakarta
}

\section{Description of Oral Health Knowledge, Oral Health Behavior, and Dental Status of the Elderly at Panti Wreda Surakarta}

\author{
Morita Sari*1, Nur Fatihah Jannah ${ }^{2}$ \\ Fakultas Kedokteran Gigi Universitas Muhammadiyah Surakarta, Surakarta, Indonesia \\ *Penulis Korespondensi \\ 1․morita.sari@gmail.com, ${ }^{2}$ nurfatihahjannah@gmail.com
}

Riwayat Artikel: Dikirim 30 Maret 2021; Diterima 6 Mei 2021; Diterbitkan 31 Mei 2021

\begin{abstract}
Abstrak
Lansia adalah setiap orang yang berusia 60 tahun atau lebih, yang secara fisik terlihat berbeda dengan kelompok usia lainnya. Pengetahuan merupakan faktor yang membentuk perilaku seseorang. Perilaku seseorang memiliki peranan penting dalam menetukan kesehatan gigi mulut. Salah satu kondisi yang sering terjadi pada rongga mulut lansia yaitu kehilangan gigi yang disebabkan oleh karies gigi. Penelitian ini dilakukan untuk mengetahui gambaran pengetahuan kesehatan gigi mulut, perilaku kesehatan gigi mulut, dan status gigi pada lansia di Panti Wreda Surakarta. Jenis Penelitian ini adalah deskriptif observasional dengan cross sectional design. Teknik pengambilan sampel menggunakan total sampling yang sesuai dengan kriteria inklusi dan eksklusi. Sampel yang digunakan sebanyak 55 orang. Analisis data dilakukan menggunakan metode deskriptif survey. Berdasarkan data yang diperoleh menunjukan bahwa dari keseluruhan lansia di Panti Wreda Surakarta yang berjumlah 55 orang memiliki tingkat pengetahuan dengan kategori sedang sebanyak 30 orang $(54,6 \%)$ dan perilaku kesehatan gigi mulut dengan kategori sedang sebanyak 40 orang $(72,7 \%)$. Status gigi geligi lansia menunjukan bahwa lansia yang mengalami karies gigi sebanyak 41 orang (74,6\%), gigi yang dicabut atau hilang sebanyak 53 orang (96,4\%), gigi yang di tambal sebanyak 6 orang $(10,9 \%)$, dan gigi yang goyah sebanyak 4 orang (7,3\%). Penelitian ini menunjukkan bahwa tingkat pengetahuan kesehatan gigi mulut lansia dan perilaku kesehatan gigi mulut lansia yang tinggal di Panti Wreda Surakarta termasuk dalam kategori sedang. Status gigi geligi lansia menunjukkan bahwa sebagian besar lansia sudah kehilangan banyak gigi-giginya yang disebabkan karena karies gigi dan sisa akar pada gigi.
\end{abstract}

Kata kunci: Lansia, Pengetahuan, Perilaku, Status gigi geligi.

\begin{abstract}
Elderly is every person aged 60 years or older, who physically looks different from other age groups. Knowledge is a factor that shapes a person's behavior. A person's behavior has an important role in determining oral health. One of the conditions that often occurs in the oral cavity of the elderly is tooth loss caused by dental caries. The results of the Basic Health Research (RIS KESDAS 2018) states that the Indonesian population who have dental and mouth problems with a proportion of 55-64 years of age as much as $61.9 \%$ and aged $>65$ years as much as $54.2 \%$. This research was conducted in order to measure the description of oral health knowledge, oral health behavior, and dental status in the elderly at Panti Wreda Surakarta. This study used a observasional descriptive with a cross sectional design. The sampling technique use total sampling that matches the inclusion and exclusion criteria. The sample used 55 people. Analysis of the data processed with descriptive survey method. Based on the data obtained shows that of the total of 55 elderly people have a medium level of knowledge of 30 people $(54.6 \%)$ and oral health behaviors with a moderate category of 40 people (72.7\%). The status of elderly teeth shows that the elderly who have dental caries are 41 people $(74.6 \%)$, the tooth extracted or missing are 53 people (96.4\%), the filled teeth are as many as 6 people (10.9\%), and wobbly teeth as much as 4 people (7.3\%). This study shows that the oral health knowledge of the elderly and oral health behavior of the elderly who live in Surakarta Nursing Homes is included in the moderate category. The status of older teeth shows that most of the elderly have lost many of their teeth due to dental caries and radix of the teeth.
\end{abstract}

Keywords: Elderly, Knowledge, Behavior, Dental Status. 


\section{PENDAHULUAN}

Lanjut usia (lansia) adalah setiap individu yang berusia 60 tahun atau lebih, yang secara fisik terlihat berbeda dengan kelompok usia lainnya. Penuaan merupakan proses alami perubahan jaringan tubuh dan organ yang sangat kompleks yang dialami oleh setiap manusia, termasuk perubahan pada jaringan rongga mulut (Yuditami, 2015). Perubahan yang terjadi pada jaringan rongga mulut akan menyebabkan karies (gigi berlubang) dan penyakit periodontal yang merupakan penyebab lansia kehilangan giginya. ${ }^{[12]}$

Lansia sering kali mengabaikan kebersihan gigi mulut dan sering mengeluh sakit gigi seperti gigi goyah, gigi berlubang, atau gusi bengkak (Senjaya, 2016). Oleh karena itu, tenaga kesehatan perlu menekankan aspek pengetahuan, pencegahan, dan pengobatan pada lansia agar tidak terjadi penyakit yang lainnya (Laela, 2013).

Pengetahuan lansia mengenai kesehatan gigi dan mulut merupakan salah satu faktor penting yang mempengaruhi kebersihan dan kesehatan gigi mulut (Nidyawati, 2013). Pengetahuan merupakan faktor yang membentuk perilaku seseorang (Tandra, 2018). Perilaku kesehatan adalah sesuatu yang berkaitan dengan tindakan individu dalam memelihara dan meningkatkan kesehatan (Adhiatmitha, 2018). Menurut teori Blum, bahwa perilaku merupakan salah satu faktor penting yang menentukan kesehatan gigi dan mulut (Astuti, 2018).

Kesehatan gigi dan mulut pada lansia merupakan suatu peranan yang sangat penting karena sangat erat kaitannya dengan kesehatan umum pada lansia. ${ }^{[16]}$ Salah satu kondisi yang sering terjadi pada rongga mulut lansia yaitu kehilangan gigi. Kehilangan gigi paling banyak dapat disebabkan akibat buruknya status kesehatan gigi dan mulut terutama karies gigi (Senjaya, 2016).
Hasil Riset Kesehatan Dasar (2018) menyatakan penduduk Indonesia yang memiliki masalah gigi dan mulut dengan proporsi usia 55-64 tahun sebanyak 61,9\% dan usia $>65$ tahun sebanyak 54,2\%. Di provinsi Jawa Tengah terdapat 56,7 \% penduduk yang mengalami masalah gigi dan mulut.

Masalah gigi yang sering terjadi di Indonesia yaitu gigi berlubang, gigi hilang atau dicabut, gigi ditambal, dan gigi goyah. Kelompok usia 55-64 tahun yang mengalami gigi berlubang sebesar 48,5\%, gigi hilang atau dicabut sebesar $29 \%$, gigi ditambal sebesar $4,2 \%$, serta gigi goyah sebesar $15,9 \%$ dan usia $>65$ tahun yang mengalami gigi berlubang sebesar $38,6 \%$, gigi hilang atau dicabut sebesar $30,6 \%$, gigi ditambal sebesar 3,1\%, serta gigi goyah sebesar 15,5\% (Kementrian Kesehatan RI, 2018).

Hasil survei yang telah dilakukan, lansia yang tinggal di Panti Wreda Dharma Bakti dan Panti Wreda Dharma Bakti Kasih Surakarta sebagian besar masih kurang dalam memelihara kesehatan gigi mulut karena fasilitas kesehatan gigi mulut dan pemeliharaan kesehatan gigi mulut yang seadanya serta belum pernah dilakukan penyuluhan tentang kesehatan gigi dan mulut. Berdasarkan gambaran di atas, maka peneliti tertarik untuk melakukan penelitian mengenai gambaran pengetahuan kesehatan gigi mulut, perilaku kesehatang gigi mulut, dan status gigi lansia di Panti Wreda Surakarta pada bulan Maret 2020.

\section{METODE}

Metode penelitian yang digunakan adalah penelitian deskriftif observasional. Penelitian ini untuk memberikan:

a. Gambaran pengetahuan kesehatan gigi mulut yang dilakukan kuesioner dengan wawancara yang dimodifikasi dengan skala guttman sebanyak 10 pertanyaan dengan 2 opsi jawaban yaitu benar dan salah; 
b. Gambaran perilaku kesehatan gigi mulut yang dilakukan kuesioner dengan wawancara yang dimodifikasi dengan skala likert sebanyak 10 pertanyaan dengan 3 opsi jawaban yaitu selalu, kadang-kadang, dan tidak pernah, serta gambaran status gigi geligi lansia yang dilakukan dengan cara melihat kondisi kesehatan gigi mulut lansia menggunakan alat diagnostic set berupa kaca mulut dan sonde serta hasil pemeriksaan dicatat pada formulir pemeriksaan gigi geligi.

Teknik pengambilan sampel yaitu total sampling dimana sampel yang diambil dari keseluruhan jumlah populasi yang sesuai dengan kriteria inklusi dan kriteria eksklusi sejumlah 55 orang. Kriteria Inklusi: lansia usia lebih dari 60 tahun,lansia tidak dalam kondisi sakit secara fisik maupun mental, dan lansia yang minimal 6 bulan tinggal di Panti Wreda Surakarta.

Kriteria Eksklusi: lansia yang memiliki keterbatasan fisik maupun mental dan lansia yang memiliki penyakit demensia. Analisis data dilakukan menggunakan metode deskriptif survey dengan cara menguraikan dan mengelompokan datadata. Data penelitian ini diolah secara manual dan disajikan dalam bentuk tabel frekuensi distribusi.

\section{HASIL DAN PEMBAHASAN}

Penelitian ini dilakukan di dua Panti Wreda Surakarta yaitu Panti Wreda Dharma Bakti dan Panti Wreda Dharma Bakti Kasih Surakarta pada bulan Maret 2020. Responden yang dilakukan pemeriksaan berjumlah 55 orang. Hasil penelitian ini mengenai gambaran pengetahuan kesehatan gigi mulut, perilaku kesehatan gigi mulut dan status gigi geligi pada lansia di Panti Wreda Surakarta pada bulan Maret 2020.

\section{Deskripsi Karakteristik Responden 1. Jenis Kelamin}

Tabel 1:

Distribusi Frekuensi Jenis Kelamin Responden

\begin{tabular}{|c|c|c|}
\hline & $\begin{array}{c}\text { Laki-laki } \\
\text { N }(\%)\end{array}$ & $\begin{array}{c}\text { Perempuan } \\
\text { N }(\%)\end{array}$ \\
\hline $\begin{array}{c}\text { Panti Wreda } \\
\text { Dharma Bakti }\end{array}$ & $17(31)$ & $18(32,7)$ \\
\hline $\begin{array}{c}\text { Panti Wreda } \\
\text { Dharma Bakti } \\
\text { Kasih }\end{array}$ & $7(12,7)$ & $13(23,6)$ \\
\hline Total & $\mathbf{2 4}(\mathbf{4 3 , 7 )}$ & $\mathbf{3 1 ( 5 6 , 3 )}$ \\
\hline
\end{tabular}

Berdasarkan table 1 menunjukkan bahwa jumlah responden terbanyak yaitu perempuan sebanyak 31 orang $(56,3 \%)$.

\section{Rentang Usia}

Tabel 2:

Diagram Distribusi Frekuensi Rentang Usia

Responden

\begin{tabular}{|c|c|c|c|}
\hline $\begin{array}{c}\text { Rentang Usia } \\
\text { (tahun) }\end{array}$ & $\begin{array}{c}60-74 \\
\mathrm{~N}(\%)\end{array}$ & $\begin{array}{c}75-89 \\
\mathrm{~N}(\%)\end{array}$ & $\begin{array}{c}>90 \\
\mathrm{~N}(\%)\end{array}$ \\
\hline Panti Wreda & 24 & 11 & 0 \\
Dharma Bakti & $(43,7)$ & $(20)$ & $(0)$ \\
\hline Panti Wreda & 12 & 8 & 0 \\
$\begin{array}{c}\text { Dharma Bakti } \\
\text { Kasih }\end{array}$ & $(21,8)$ & $(14,5)$ & $(0)$ \\
\hline Total & $\mathbf{3 6}$ & $\mathbf{1 9}$ & $\mathbf{0}$ \\
$\mathbf{( 6 5 , 5 )}$ & $\mathbf{( 3 4 , 5 )}$ & $\mathbf{( 0 )}$ \\
\hline
\end{tabular}

Berdasarkan table 2 menunjukan bahwa jumlah lansia paling banyak yang menetap di Panti Wreda yaitu dengan rentang usia 60-74 tahun sebanyak 36 orang $(65,5 \%)$. Hal ini karena lansia dengan rentang usia 60-74 tahun masih bisa diajak komunikasi dan masih bisa melakukan kegiatan sehari-hari dengan baik, sehingga mereka dapat ikut berpartisipasi dalam kegiatan yang diadakan dari pihak panti. 


\section{Tingkat Pendidikan}

Tabel 3:

Diagram Distribusi Pendidikan Responden

\begin{tabular}{|c|c|c|c|c|}
\hline $\begin{array}{c}\text { Pendidikan } \\
\text { Terakhir }\end{array}$ & क क $\frac{e^{\circ}}{z}$ & $\sum_{\infty}^{e} \frac{e}{Z}$ & $\sum_{\infty}^{\infty} \frac{e}{Z}$ & 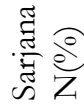 \\
\hline $\begin{array}{c}\text { Panti Wreda } \\
\text { Dharma } \\
\text { Bakti }\end{array}$ & $\begin{array}{c}3 \\
(5,5)\end{array}$ & $\begin{array}{c}9 \\
(16,4)\end{array}$ & $\begin{array}{c}19 \\
(34,5)\end{array}$ & $\begin{array}{c}4 \\
(7,3)\end{array}$ \\
\hline $\begin{array}{c}\text { Panti Wreda } \\
\text { Dharma } \\
\text { Bakti Kasih }\end{array}$ & $\begin{array}{c}1 \\
(1,8)\end{array}$ & $\begin{array}{c}4 \\
(7,3)\end{array}$ & $\begin{array}{c}8 \\
(14,5)\end{array}$ & $\begin{array}{c}7 \\
(12,7)\end{array}$ \\
\hline Total & $\begin{array}{c}4 \\
(7,3)\end{array}$ & $\begin{array}{c}13 \\
(23,7)\end{array}$ & $\begin{array}{c}27 \\
(49)\end{array}$ & $\begin{array}{c}11 \\
(20)\end{array}$ \\
\hline
\end{tabular}

Berdasarkan tabel 3 menunjukan bahwa pendidikan lansia di Panti Wreda mayoritas berpendidikan Sekolah Menengah Atas (SMA) yaitu sebanyak 27 orang $(49 \%)$.

\section{Frekuensi Tingkat Pengetahuan Kesehatan Gigi Mulut}

Tabel 4:

Distribusi Frekuensi Pengetahuan Kesehatan Gigi Mulut Lansia

\begin{tabular}{|c|c|c|}
\hline $\begin{array}{l}\text { Pengetahuan Kesehatan } \\
\text { Gigi Mulut }\end{array}$ & 胥 巳 & $\frac{\frac{\pi}{3}}{\text { की }} \frac{8}{Z}$ \\
\hline $\begin{array}{l}\text { Kesehatan gigi dan mulut } \\
\text { mempengaruhi kondisi } \\
\text { kesehatan umum. }\end{array}$ & $\begin{array}{c}44 \\
(80)\end{array}$ & $\begin{array}{c}11 \\
(20)\end{array}$ \\
\hline $\begin{array}{l}\text { Menyikat gigi dua kali sehari } \\
\text { ketika mandi pagi dan mandi } \\
\text { sore. }\end{array}$ & $\begin{array}{c}14 \\
(25,5)\end{array}$ & $\begin{array}{c}41 \\
(74,5)\end{array}$ \\
\hline $\begin{array}{l}\text { Bentuk sikat gigi yang baik yaitu } \\
\text { memiliki bulu sikat yang kasar } \\
\text { dengan ujung kepala sikat } \\
\text { mengecil. }\end{array}$ & $\begin{array}{c}40 \\
(72,7)\end{array}$ & $\begin{array}{c}15 \\
(27,3)\end{array}$ \\
\hline $\begin{array}{l}\text { Saat menyikat gigi, lidah perlu } \\
\text { disikat. }\end{array}$ & $\begin{array}{c}21 \\
(38,2)\end{array}$ & $\begin{array}{c}34 \\
(61,8)\end{array}$ \\
\hline $\begin{array}{l}\text { Lansia yang tidak mempunyai } \\
\text { gigi sama sekali, setiap habis } \\
\text { makan tidak perlu berkumur } \\
\text { kumur, }\end{array}$ & $\begin{array}{c}40 \\
(72,7)\end{array}$ & $\begin{array}{c}15 \\
(27,3)\end{array}$ \\
\hline $\begin{array}{l}\text { Saat tidur gigi palsu sebaiknya } \\
\text { tetap di pakai. }\end{array}$ & $\begin{array}{c}15 \\
(27,3)\end{array}$ & $\begin{array}{c}40 \\
(72,7)\end{array}$ \\
\hline $\begin{array}{l}\text { Gigi palsu harus selalu } \\
\text { dibersihkan. }\end{array}$ & $\begin{array}{c}49 \\
(89,1)\end{array}$ & $\begin{array}{c}6 \\
(10,9)\end{array}$ \\
\hline
\end{tabular}

\begin{tabular}{|c|c|c|}
\hline $\begin{array}{l}\text { Pengetahuan Kesehatan } \\
\text { Gigi Mulut }\end{array}$ & 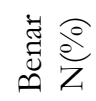 & 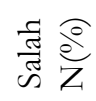 \\
\hline $\begin{array}{l}\text { Makanan manis dan lengket } \\
\text { dapat merusak gigi }\end{array}$ & $\begin{array}{c}44 \\
(80)\end{array}$ & $\begin{array}{c}11 \\
(20)\end{array}$ \\
\hline $\begin{array}{l}\text { Periksa ke dokter gigi secara } \\
\text { rutin sebaiknya dilakukan } \\
\text { minimal } 6 \text { bulan sekali }\end{array}$ & $\begin{array}{c}18 \\
(32,7)\end{array}$ & $\begin{array}{c}37 \\
(67,3)\end{array}$ \\
\hline $\begin{array}{l}\text { Merokok tidak mempengaruhi } \\
\text { kesehatan yang ada di rongga } \\
\text { mulut }\end{array}$ & $\begin{array}{c}38 \\
(69,1)\end{array}$ & $\begin{array}{c}17 \\
(30,9)\end{array}$ \\
\hline
\end{tabular}

Kesehatan gigi dan mulut pada lansia merupakan suatu peranan yang sangat penting karena sangat erat kaitannya dengan kesehatan umum lansia (Yuditami, 2015). Lansia sebanyak 44 orang $(80 \%)$ mengetahui bahwa kesehatan gigi mulut mempunyai pengaruh terhadap kesehatan umum pada tubuh. Pada tabel 4 menunjukan kurangnya pengetahuan lansia tentang menyikat gigi dengan benar yaitu sebanyak 41 orang $(74,5 \%)$ yang mengetahui menyikat gigi rutin dua kali sehari dilakukan ketika mandi pagi dan mandi sore dan sebanyak 34 orang $(61,8 \%)$ yang mengetahui lidah tidak perlu disikat ketika menyikat gigi, serta kurangnya pengetahuan lansia tentang periksa ke dokter gigi yang benar hanya sebanyak 18 orang $(32,7 \%$ ) yang mengetahui periksa ke dokter gigi dilakukan secara rutin minimal 6 bulan sekali. Hal ini karena lansia yang tinggal di Panti Wreda Surakarta menyatakan tidak perlu rutin menyikat gigi dan tidak perlu rutin memeriksakan giginya ke dokter gigi karena beranggapan sudah tidak memiliki gigi atau ompong. Lansia sebanyak 40 orang $(72,7 \%)$ menjawab dengan benar kalau lansia yang tidak mempunyai gigi sama sekali, setelah selesai makan harus berkumur-kumur. Hal ini senada dengan pendapat Senjaya (2016) yang menyatakan bahwa lansia yang tidak mempunyai gigi sama sekali, setelah selesai makan seharusnya langsung berkumurkumur dan menyikat lidah dan gusi untuk membersihkan sisa makanan yang melekat (Senjaya, 2016). 
Hasil dari tabel 4 menunjukan bahwa lansia yang mengetahui gigi palsu sebaiknya dilepas ketika tidur hanya sebanyak 15 orang $(27,3 \%)$ dari 55 orang yang tingal di Panti Wreda. Hal ini disebabkan karena lansia di Panti Wreda beranggapan gigi palsu merupakan bagian dari rongga mulut yang harus selalu ada di dalam rongga mulut dan tidak perlu untuk dilepas ketika hendak tidur. Menurut Muluwaere et al (2015) bahwa gigi palsu harus dilepas dari mulut ketika hendak tidur untuk mengurangi patahnya gigi palsu dan agar kebersihan gigi palsu, serta ronga mulut tetap terjaga (Muluwere, 2015). Lansia yang tinggal di Panti Wreda sebagian besar mengetahui kalau gigi palsu harus selalu dibersihkan sebanyak 49 orang $(89,1 \%)$. Hal ini sesuai dengan penelitian Muluwaere et al (2015) bahwa penggunaan gigi palsu harus selalu memperhatikan kebersihan gigi tiruannya untuk mencegah kehilangan gigi lebih lanjut, terjadinya peradangan pada mukosa mulut di bagian bawah gigi palsu, terbentuknya plak pada gigi palsu, serta berkembangnya mikroorganisme yang merugikan pada rongga mulut seperti jamur candida albicans (Muluwere, 2015).

Dilihat dari tabel 4 menunjukan bahwa lansia yang memiliki pengetahuan tentang makanan manis dan lengket dapat merusak gigi sebanyak 44 orang $(80 \%)$. Hal ini senada dengan pendapat Senjaya (2016) bahwa mengatur pola makan dengan menghindari makanan yang manis yang banyak mengandung gula dan lengket mencegah terjadinya kerusakan pada gigi (Senjaya, 2016). Lansia yang memiliki pengetahuan tentang merokok mempengaruhi kesehatan rongga mulut sebanyak 38 orang $(69,1 \%)$. Hal ini sesuai dengan penelitian Diba et al, 2016 bahwa merokok dapat mempengaruhi tingkat kebersihan gigi mulut yang dapat menimbulkan penyakit pada rongga mulut (Diba, 2012). Kandungan rokok yang toksik dapat mengiritasi jaringan lunak rongga mulut yang akan menyebabkan infeksi pada mukosa, $d r y$ socket, penyembuhan luka menjadi lambat, serta dapat menyebabkan berkurangnya asupan aliran darah masuk ke gingiva (Kusuma, 2011).

Tabel 5:

Distribusi Kriteria Pengetahuan Kesehatan Gigi Mulut Lansia

\begin{tabular}{|c|c|}
\hline $\begin{array}{c}\text { Pengetahuan Kesehatan } \\
\text { Gigi dan Mulut }\end{array}$ & N $(\%)$ \\
\hline Rendah & $7(12,7)$ \\
\hline Sedang & $30(54,6)$ \\
\hline Tinggi & $18(32,7)$ \\
\hline Total & $\mathbf{5 5 ( 1 0 0 )}$ \\
\hline
\end{tabular}

Berdasarkan tabel 5 menunjukan bahwa dari keseluruhan lansia yang berjumlah 55 orang, sebagian besar lansianya memiliki tingkat pengetahuan kesehatan gigi mulut dengan kategori sedang (skor 4-6) sebanyak 30 orang $(54,6 \%)$. Menurut peneliti bahwa lansia yang tinggal di Panti Wreda sebagian besar sudah cukup memperoleh pengetahuan kesehatan gigi mulut, karena mayoritas lansia yang tinggal di Panti Wreda berpendidikan Sekolah Menengah Atas. Status Pendidkan merupakan salah satu faktor yang mempengaruhi tingkat pengetahuan (Nidyawati, 2013).

\section{Frekuensi Perilaku Kesehatan Gigi Mulut}

Tabel 6:

Distribusi Frekuensi Perilaku Kesehatan Gigi Mulut Responden

\begin{tabular}{|c|c|c|c|}
\hline $\begin{array}{c}\text { Perilaku Kesehatan } \\
\text { Gigi Mulut }\end{array}$ & $\frac{3}{\frac{3}{0}} \frac{\partial}{2}$ & 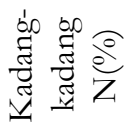 & 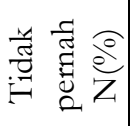 \\
\hline $\begin{array}{l}\text { Menyikat gigi dua } \\
\text { kali dalam sehari }\end{array}$ & $\begin{array}{c}47 \\
(85,5)\end{array}$ & $\begin{array}{c}8 \\
(14,5) \\
\end{array}$ & $\begin{array}{c}0 \\
(0) \\
\end{array}$ \\
\hline $\begin{array}{l}\text { Menyikat gigi saat } \\
\text { mandi pagi dan } \\
\text { mandi sore }\end{array}$ & $\begin{array}{c}42 \\
(76,4)\end{array}$ & $\begin{array}{c}10 \\
(18,2)\end{array}$ & $\begin{array}{c}3 \\
(5,4)\end{array}$ \\
\hline $\begin{array}{l}\text { Menyikat gigi } \\
\text { bagian gusi dan } \\
\text { lidah }\end{array}$ & $\begin{array}{l}33 \\
(60)\end{array}$ & $\begin{array}{c}6 \\
(10,9)\end{array}$ & $\begin{array}{c}16 \\
(29,1)\end{array}$ \\
\hline
\end{tabular}




\begin{tabular}{|c|c|c|c|}
\hline $\begin{array}{l}\text { Perilaku Kesehatan } \\
\text { Gigi Mulut }\end{array}$ & 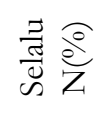 & 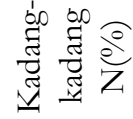 & 离 \\
\hline $\begin{array}{l}\text { Menyikat gigi pada } \\
\text { seluruh permukaan } \\
\text { gigi }\end{array}$ & $\begin{array}{c}43 \\
(78,2)\end{array}$ & $\begin{array}{c}6 \\
(10,9)\end{array}$ & $\begin{array}{c}6 \\
(10,9)\end{array}$ \\
\hline $\begin{array}{l}\text { Menyikat gigi } \\
\text { menggunakan } \\
\text { pasta gigi } \\
\text { berfluoride }\end{array}$ & $\begin{array}{c}51 \\
(92,8)\end{array}$ & $\begin{array}{c}2 \\
(3,6)\end{array}$ & $\begin{array}{c}2 \\
(3,6)\end{array}$ \\
\hline $\begin{array}{l}\text { Menyikat gigi } \\
\text { setelah makan pagi } \\
\text { dan malam } \\
\text { sebelum tidur }\end{array}$ & $\begin{array}{c}26 \\
(47,3)\end{array}$ & $\begin{array}{c}21 \\
(38,2)\end{array}$ & $\begin{array}{c}8 \\
(14,5)\end{array}$ \\
\hline $\begin{array}{l}\text { Memakan } \\
\text { makanan manis } \\
\text { atau lengket }\end{array}$ & $\begin{array}{c}12 \\
(21,8)\end{array}$ & $\begin{array}{c}26 \\
(47,3)\end{array}$ & $\begin{array}{c}17 \\
(30,9)\end{array}$ \\
\hline $\begin{array}{l}\text { Memakan buah- } \\
\text { buahan dan sayur- } \\
\text { sayuran }\end{array}$ & $\begin{array}{c}47 \\
(85,5)\end{array}$ & $\begin{array}{c}8 \\
(14,5)\end{array}$ & $\begin{array}{c}0 \\
(0)\end{array}$ \\
\hline $\begin{array}{l}\text { Mengunjungi } \\
\text { dokter gigi } 6 \text { bulan } \\
\text { sekali }\end{array}$ & $\begin{array}{c}0 \\
(0)\end{array}$ & $\begin{array}{c}7 \\
(12,7)\end{array}$ & $\begin{array}{c}48 \\
(87,3)\end{array}$ \\
\hline $\begin{array}{l}\text { Mengunjungi } \\
\text { dokter gigi ketika } \\
\text { gigi berlubang }\end{array}$ & $5(9,1)$ & $\begin{array}{c}15 \\
(27,3)\end{array}$ & $\begin{array}{c}35 \\
(63,6)\end{array}$ \\
\hline
\end{tabular}

Pengetahuan kesehatan gigi merupakan hal yang mempengaruhi perilaku individu dalam memelihara kesehatan gigi dan mulut (Rahayu, 2014). Hasil dari tabel 6 berdasarkan perilaku menyikat gigi menunjukan bahwa lebih dari 50\% lansia selalu menyikat gigi dua kali sehari sebanyak 47 orang $(85,5 \%)$, menyikat gigi saat mandi pagi dan mandi sore sebanyak 42 orang $(76,4 \%)$. menyikat gigi bagian gusi dan lidah sebanyak 33 orang $(60 \%)$, menyikat gigi pada seluruh permukaan gigi sebanyak 43 orang $(78,2 \%)$, serta menyikat gigi dengan menggunakan fluoride sebanyak 51 orang (92,8\%).

Perilaku menyikat gigi yang benar dan rutin sangat berpengaruh terhadap kesehatan pada rongga mulut. Hal ini sesuai dengan penelitian Juwita (2013) menyatakan bahwa perilaku menyikat gigi yang dilakukan dengan benar seperti menyikat gigi rutin 2 kali sehari, menyikat gigi setelah makan, lama proses menyikat gigi 2-3 menit, serta penggunaan pasta gigi berfluoride merupakan faktor-faktor yang dapat mencegah karies gigi yang menyebabkan kehilangan gigi. ${ }^{[6]}$ Kurang dari $50 \%$ lansia yang selalu menyikat gigi setelah makan pagi dan malam sebelum tidur sebanyak 26 orang $(47,3 \%)$. Menyikat sebelum tidur sangat efektif untuk mencegah karies gigi atau kehilangan gigi. Hal ini sesuai dengan penelitian Budisuari et al (2010) menunjukan bahwa waktu menyikat gigi setelah sarapan dan sebelum tidur sangat berpengaruh terhadap status kesehatan gigi mulut (Budisuari, 2010).

Dilihat dari tabel 6 berdasarkan perilaku pola makan menunjukan bahwa lebih dari 50\% lansia selalu makan buahbuahan dan sayur-sayuran sebanyak 47 orang $(85 \%)$. Hal ini karena dari pihak Panti Wreda sudah mengatur pola makan dan asupan nutrisi lansia dengan cara memberikan sayur-sayuran dan buahbuahan 3x sehari. Fungsi mekanik dari makanan yang dimakan yang bersifat membersihkan gigi yaitu menyikat gigi yang akan mengurangi kerusakan gigi

Makanan yang bersifat membersihkan gigi antara lain buah-buahan dan sayur-sayuran (Ernawati, 2012). Kurang dari 50\% lansia makan makanan yang manis atau lengket yaitu selalu sebanyak 12 orang $(21,8 \%)$, kadang-kadang sebanyak 26 orang $(47,3 \%)$, dan tidak pernah sebanyak 17 orang $(30,9 \%)$. Hal ini karena sebagian besar lansia yang tinggal di Panti Wreda mengetahui makanan yang manis dan lengket dapat merusak gigi. Makanan yang bersifat merusak gigi antara lain makanan manis dan lengket seperti coklat, permen, biskuit, dan lainnya (Ernawati, 2012).

Pada tabel 6 berdasarkan perilaku kunjungan ke dokter gigi menunjukan bahwa lebih dari 50\% lansia tidak pernah mengunjungi dokter gigi minimal 6 bulan sekali sebanyak 48 orang $(87,3 \%)$. Hal ini terjadi karena lansia beranggapan bahwa memeriksakan gigi ke dokter gigi apabila ada keluhan sakit gigi. Lansia tidak pernah mengunjungi dokter gigi ketika gigi 
berlubang sebanyak 35 orang $(63,6 \%)$. Hal ini karena lansia beranggapan apabila gigi berlubangnya belum terasa sakit parah maka lansia tidak akan ke dokter gigi untuk memeriksakan giginya. Pemeriksaan rutin ke dokter gigi, Puskesmas, ataupun Rumah Sakit minimal 6 bulan sekali bertujuan untuk mengetahui dan mendeteksi kelainan atau penyakit yang ada pada rongga mulut sejak dini. Gigi berlubang merupakan salah satu penyakit yang sering dikeluhkan lansia yang sebaiknya segera ke dokter gigi untuk mendapatkan penanganan lebih lanjut (Senjaya, 2016).

Tabel 7:

Distribusi Kriteria Perilaku Kesehatan Gigi Mulut Responden

\begin{tabular}{|c|c|}
\hline $\begin{array}{c}\text { Perilaku Kesehatan } \\
\text { Gigi dan Mulut }\end{array}$ & $\mathrm{N}(\%)$ \\
\hline Rendah & $5(9,1)$ \\
\hline Sedang & $40(72,7)$ \\
\hline Tinggi & $10(18,2)$ \\
\hline Total & $\mathbf{5 5}(\mathbf{1 0 0})$ \\
\hline
\end{tabular}

Berdasarkan tabel 7 menunjukan bahwa dari keseluruhan lansia yang berjumlah 55 orang, sebagian besar lansianya memiliki perilaku kesehatan gigi mulut dengan kategori sedang (skor 18-24) sebanyak 40 orang (72,7\%). Menurut peneliti bahwa perilaku lansia sudah cukup baik dalam memelihara kesehatan gigi mulut seperti menyikat gigi dua kali sehari, menyikat gigi menggunakan pasta gigi berfluoride, serta memakan buah-buhan dan sayur-sayuran, tetapi masih ada beberapa perilaku lansia dalam memelihara kesehatan gigi mulut yang masih kurang tepat misalnya lansia menyikat gigi saat mandi pagi dan mandi sore, mengunjungi dokter gigi tidak rutin minimal 6 bulan sekali ataupun memeriksakan ke dokter gigi apabila ada keluhan sakit gigi seperti gigi berlubang.

\section{Status Gigi Geligi}

Tabel 8:

Distribusi Frekuensi Status Gigi Geligi Lansia

\begin{tabular}{|c|c|}
\hline & $\begin{array}{c}\text { Responden 55 } \\
\text { Orang N }(\%)\end{array}$ \\
\hline Gigi Karies & $51(74,6)$ \\
\hline $\begin{array}{c}\text { Gigi hilang / dicabut } \\
\text { (Missing) }\end{array}$ & $6(10,9)$ \\
\hline $\begin{array}{c}\text { Gigi ditambal } \\
\text { (Filling) }\end{array}$ & $4(7,3)$ \\
\hline Gigi goyah & \\
\hline
\end{tabular}

Berdasarkan tabel 8 menunjukan bahwa lansia di Panti Wreda Surakarta yang mengalami karies gigi sebanyak 41 orang $(74,6 \%)$, gigi hilang / dicabut sebanyak 53 orang $(96,4 \%)$, gigi yang ditambal sebanyak 6 orang $(10,9 \%)$, dan gigi yang goyah sebanyak 4 orang $(7,3 \%)$. Mayoritas lansia yang tinggal di Panti Wreda Surakarta sudah tidak memiliki gigi karena giginya tanggal atau dicabut.

Pengetahuan dan perilaku lansia dalam memelihara kesehatan gigi mulut sudah cukup, tetapi status gigi geligi lansia menunnjukan bahwa masih banyak lansia mengalami karies gigi dan gigi dicabut. Hal ini mungkin karena lansia baru mengetahui cara memelihara kesehatan gigi mulut yang benar, sehingga lansia terlambat menerapkan dalam tindakan perilaku sehariharinya. Kehilangan gigi dapat menyebabkan gangguan pada rongga mulut seperti gangguan pada fungsi pengunyuhan dan fungsi berbicara dan dapat juga mempengaruhi kesehatan umum seseorang sehingga akan mempengaruhi kualitas hidup individu (Senjaya, 2016). 
Gambar 1:

Pemeriksaan Gigi Geligi Lansia

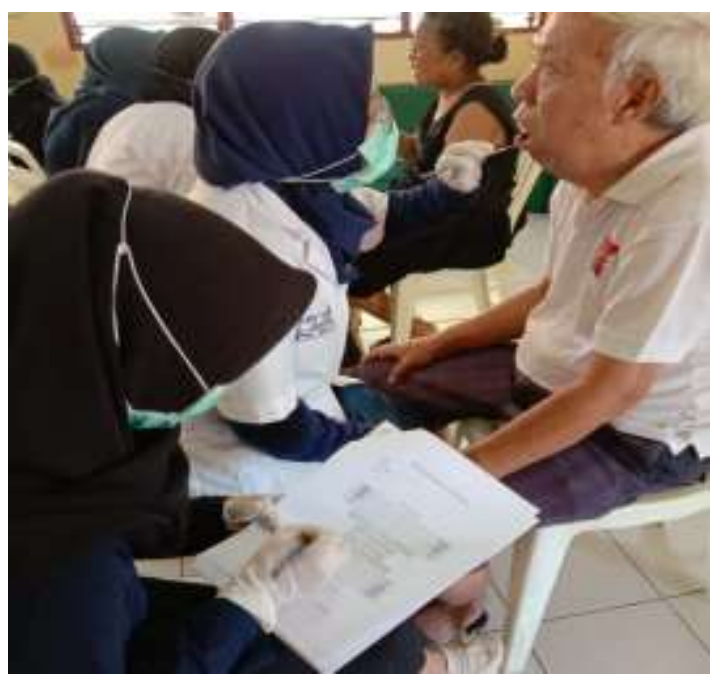

Sumber: Dokumentasi Pribadi

\section{KESIMPULAN}

Berdasarkan hasil pembahasan, maka dapat disimpulkan bahwa tingkat pengetahuan kesehatan gigi mulut lansia dan perilaku kesehatan gigi mulut lansia yang tinggal di dua Panti Wreda Surakarta termasuk dalam kategori sedang yang mana pengetahuan kesehatan gigi mulut sebanyak 30 orang $(54,6 \%)$ dan perilaku kesehatan gigi mulut sebanyak 40 orang $(72,7 \%)$.

Berdasarkan status gigi geligi lansia yang tinggal di dua Panti Wreda Surakarta yang mengalami karies gigi sebanyak 41 orang $(74,6 \%)$, gigi yang dicabut atau hilang sebanyak 53 orang $(96,4 \%)$, gigi yang di tambal sebanyak 6 orang $(10,9 \%)$, dan gigi yang goyah sebanyak 4 orang $(7,3 \%)$. Sebagian besar lansia di Panti Wreda Surakarta sudah kehilangan banyak gigigiginya yang disebabkan karena karies gigi dan sisa akar pada gigi yang menyebabkan gangguan fungsi pada rongga mulut lansia.

\section{DAFTAR PUSTAKA}

Adhiatmitha, K.E., Ni, K.F., dan Desak, N. A. (2018). Faktor-faktor yang Berkaitan dengan Tingkat Perilaku Pemeliharaan Kebersihan Gigi Tiruan Lepasan Akrilik Pada Lansia di Desa Penatahan Kabupaten
Tabanan Bali. Bali Dental Journal, 2(1), 17-23.

Astuti, N. R. (2018). Hubungan Antara Pengetahuan dan Perilaku Pemeliharaan Kesehatan Gigi dan Mulut dengan Status Kesehatan Periodontal Pada Lanjut Usia. Jurnal Ilmiah Dan Teknologi Kedokteran Gigi, 14(2), 33-36.

Budisuari, M.A., Oktarina, dan Muhammad, A. . (2010). Hubungan Pola Makan dan Kebiasaan Menyikat Gigi dengan Kesehatan Gigi dan Mulut (Karies) di Indonesia. Buletin Penelitian Sistem Kesehatan, 13(1), 83-91.

Diba, C.M., Zuraida, U.B., dan S. (2012). Hubungan Tingkat Pengetahuan Dampak Merokok Terhadap Kesehatan Rongga Mulut dengan Status Kebersihan Rongga Mulut (Remaja Desa Cot Mesjid Kecamatan Lueng Bata Kota Banda Aceh). Journal Caninus Dentistry, 1(4), 12-19.

Ernawati, Arwani, Amin, S. (2012). Hubungan Antara Perilaku Mengkonsumsi Makan Makanan Manis dan Perilaku Menggosok Gigi dengan Kejadian Karies Gigi pada Anak TK Pertiwi 37 Gunung Pati. Jurnal Keperawatan, 4(2), 183-193

Juwita, L. (2013). Perilaku Menyikat Gigi dan Insiden Karies Gigi. Jurnal Ners Lentera, 1, 22-29.

Kementrian Kesehatan RI. (2018). Laporan Nasional RISKESDAS 2018.Jakarta: Kementrian Kesehatan RI. hal.181222

Kusuma, A. R. P. (2011). Pengaruh Merokok Terhadap Kesehatan Gigi dan Rongga Mulut. Jurnal Unissula, 49(124), 1-8.

Laela, D.S., dan T. W. (2013). Analisis Faktor-faktor yang Mempengaruhi Need dan Lansia Terhadap Kesehatan Gigi dan Mulut di Kelurahan Sekeloa Coblong Bandung. Jurnal Riset Kesehatan, 61(3), 
102-109.

Muluwere, V.O., Mariati, N.W., dan Wicaksono, D. A. (2015). Gambaran Pengetahuan dan Status Kebersihan Mulut pada Pemakaian Gigi Tiruan Sebagian Lepasan di Kelurahan Batu Kota Kecamatan Malalayang. Jurnal E-Gigi, 3(1), 197-202.

Nidyawati, N., Dinar, A. . (2013). Gambaran Tingkat Pengetahuan dan Kebersihan Mulut pada Masyarakat Lanjut Usia di Kelurahan Rurukan Kecamatan Tomohon Timur. Jurnal Biomedik (JBM), 5(1), 169-174.

Prihastari, L., Puteri, M.S., Rizka, I., Sherly, M., dan Zullia, T. (2014). Survey Epidemiologi: Hubungan Antara Perilaku Kesehatan Gigi Mulut dengan Indeks DMF-T Lansia Usia 45-65 tahun di Kecamatan Kronjo, Kabupaten Tanggerang. ODONTO Dental Journal, 6(2), 101-107.

Rahayu, C., Sri, W., dan Niken, W. (2014). Hubungan Antara Pengetahuan, Sikap, dan Perilaku Terhadap Pemeliharaan Kebersihan Gigi dan Mulut dengan Status Kesehatan Periodontal Pra Lansia di Posbindu Kecamatan Indihiang Kota tasikmalaya. Maj Ked Gi, 21(1), 27-32.

Senjaya, A. A. (2016). Gigi Lansia. Jurnal Skala Husada, 21(1), 72-80.

Tandra, N.F., Christy, N.M., dan Kustina, Z. (2018). Hubungan Pengetahuan Kesehatan Gigi dan Mulut Dengan Status Kebersihan Gigi pada Penyandang Tunanetra Dewasa. Jurnal E-Gigi, 6(2), 124-129.

Yuditami, N.W., I Nyoman, W., dan Ni Wayan, A. (2015). Hubungan Pengetahuan Tentang Pemeliharaan Kesehatan Gigi dan Mulut dengan Jumlah Gigi yang Berfungsi pada Lanjut Usia di Panti Pelayanan Lanjut Usia Wana Seraya Biaung Denpasar. Jurnal Kesehatan Gigi, 3(2), 70-75. 